\title{
Application of chlorofluorocarbons (CFCs) to estimate the groundwater age at a headwater wetland in Ichikawa City, Chiba Prefecture, Japan
}

\author{
Zhiwei Han $\cdot$ Changyuan Tang $\cdot$ Jingqiu Piao $\cdot$ \\ Xing Li • Yingjie Cao • Touma Matsumaru • \\ Chipeng Zhang
}

Received: 23 May 2013/Accepted: 27 November 2013/Published online: 20 December 2013

(C) The Author(s) 2013. This article is published with open access at Springerlink.com

\begin{abstract}
To delineate the groundwater flow system in a basin, the groundwater age was estimated by analyzing chlorofluorocarbons (CFC-11, CFC-12 and CFC-113) in a typical headwater wetland in Ichikawa, Japan. Feasibility of groundwater dating by CFCs was assessed comprehensively based on the concentrations of $\mathrm{NO}_{3}{ }^{-}, \mathrm{SO}_{4}{ }^{2-}, \mathrm{Fe}^{2+}$ and dissolved $\mathrm{CH}_{4}$ in the groundwater, because the CFCs would be degraded under the reduction condition available in a wetland. It was found that the CFC-11 apparent age was much older than that estimated by other CFC species. It showed that CFC-12 and CFC-113 were suitable tracers for groundwater dating because of their stability in the wetland environment. Furthermore, the mixture of groundwater with different age was discussed by CFC-12 and CFC-113 based on the binary mixing model and piston-flow model. As a result, the apparent age of groundwater in the study area is in the range of $38-48$ years.
\end{abstract}

\footnotetext{
Z. Han · C. Tang $(\bowtie) \cdot$ J. Piao · X. Li · Y. Cao · T. Matsumaru .

C. Zhang

Graduate School of Horticulture, Faculty of Horticulture,

Chiba University, Matsudo 271-8510, Japan

e-mail: tangchangyuan@gmail.com

Z. Han

e-mail: hanzhiwei82@gmail.com

J. Piao

e-mail: aki.g2012@gmail.com

X. Li

e-mail: 1xbaboon@163.com

Y. Cao

e-mail: wowcyj@gmail.com

T. Matsumaru

e-mail: mattohma19@gmail.com

C. Zhang

e-mail: cpzhang759@126.com
}

Keywords Reduction condition - CFCs - Groundwater age $\cdot$ Mixing model $\cdot$ Groundwater flow

\section{Introduction}

As one of the most active factors, groundwater age is a key to understand the hydrological cycle as well as the associated hydro-ecological processes in a watershed. The knowledge of the residence time would also help to illuminate processes that control subsurface flow routing since it is directly related to the diversity of flow pathways in a catchment (Pearce et al. 1986; OWENS 1991; Kirchner et al. 2001). There are many ways to identify the residence time. For example, tritium $\left({ }^{3} \mathrm{H}\right)$ is used to estimate residence times, but the method is difficult to use since the tritium concentration is too low to be detectable at present (DeWalle et al. 1997; Małoszewski and Zuber 1982; Uhlenbrook 2002). Historical tracers are those which are present as a result of human activity, and the concentrations of tracers changed in the past time obey a given rules (Selaolo 1998). Consequently, the residence time of springs and groundwater can be indicated by the use of these historical tracers such as CFC-11, CFC-12, CFC-113, $\mathrm{SF}_{6},{ }^{85} \mathrm{Kr},{ }^{3} \mathrm{H}$ and ${ }^{3} \mathrm{H} /{ }^{3} \mathrm{He}$ (Happell et al. 2006; Darling and Gooddy 2007; Visser et al. 2009; Alvarado et al. 2005). Moreover, the atmospheric history of CFCs has been well established (Wisegarver and Gammon 1988; Walker et al. 2000; Thompson et al. 2004). Numerous studies of groundwater flow system have demonstrated good agreement between CFCs ages and the ages estimated independently with ${ }^{3} \mathrm{H} /{ }^{3} \mathrm{He}$ for 0 to 50 -year-old groundwater (Busenberg and Plummer 1992; Plummer et al. 2001; Dunkle et al. 1993). Compared with some groundwater dating techniques, CFCs can be determined 
Fig. 1 Location of sampling sites in artificial wetland catchment of Ichikawa City

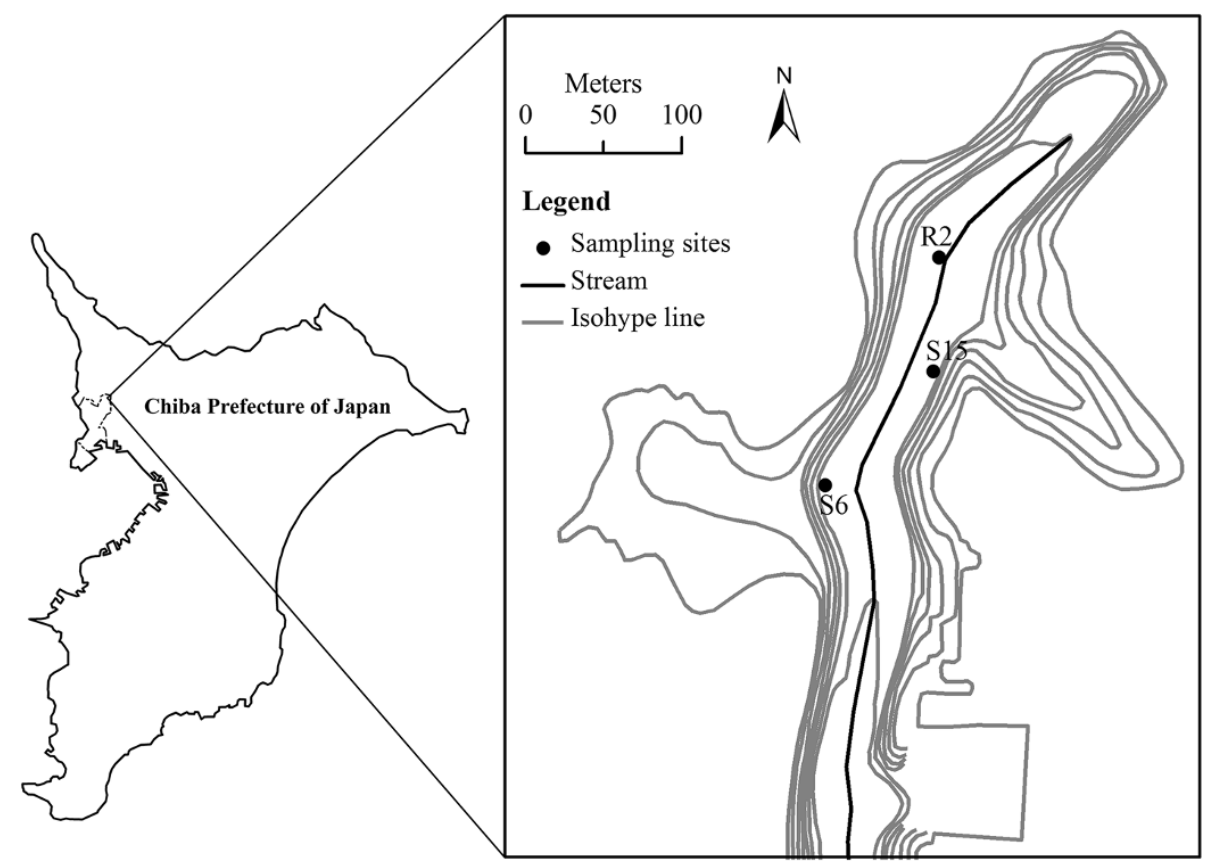

rapidly without sophisticated sampling and analytical instrument. Therefore, it provides a cost-effective tool to understand the groundwater flow system. Laboratory and field studies have consistently shown that CFCs are stable in the aerobic environments and their concentrations of groundwater can reflect atmospheric values at the time of recharge (Oster et al. 1996; Dunkle et al. 1993). CFC-12 is considered as the most resistant to the degradation, whereas CFC-11 and CFC-113 degrade more easily (Lovley and Woodward 1992; Denovan and Strand 1992; IAEA 2006).

Wetlands play an important role in climatic regulation, water conservation and purification, and the maintenance of biological diversity. However, their functions can easily be disturbed in areas with over-exploitations. Wetlands are typically highly productive ecosystems with soils containing high levels of labile organic matter (Kadlec and Wallace 2008; Nguyen 2000). When groundwater moves through wetlands, aerobic condition in shallow groundwater could easily become anoxic condition because of the consumption of the available oxygen during decomposition processes (Seitzinger 1994). Though CFCs are useful tracers in hydrological cycle and can also provide valuable information to estimate groundwater age in watersheds, its use in wetland is still uncertain because of the effect of anoxic environment on CFCs in the groundwater. Therefore, the objective of this study were (1) to determine the stability of CFCs over a range of redox conditions in the wetland environment, and (2) to estimate the apparent age of groundwater using a binary mixing model (BMM).

\section{Description of study area}

The headwater wetland $\left(35.76^{\circ} \mathrm{N}, 139.97^{\circ} \mathrm{E}\right)$ in Ichikawa City, Chiba Prefecture, Japan was selected as the study area (Fig. 1). The mean annual temperature is $14.8{ }^{\circ} \mathrm{C}$, and the mean annual precipitation is about $1,313.8 \mathrm{~mm}$. The land use was the paddy field about 30 years ago and it has been redeveloped to a wetland park since then. Pear plantation is prevailing in the upland where much manure is applied. Elevations of upland and wetland are about 30 and $12 \mathrm{~m}$, respectively. The upland is covered by Kanto loam (4 m thick). The underlain strata are Joso clay layer ( $2 \mathrm{~m}$ thick) and Narita sand layer (22 m thick) in sequence. Narita sand layer extends to the wetland as the major aquifer in the study area. A thin layer of cohesive soil and sandy clay covers the wetland surface.

The water table in the upland is around $8 \mathrm{~m}$. The springs and upward groundwater recharge the river flowing through the wetland valley. Observation sites of R2, S6 and, S15 are located at the middle and at the two sides of wetland valley, respectively. Piezometers were set at the depths of $1 \mathrm{~m}, 2 \mathrm{~m}$ and $3 \mathrm{~m}$ at each site.

\section{Methods}

Sampling

Groundwater samples were collected from the piezometers in March, 2011. Initially, whole water in the piezometer was withdrawn out to let fresh groundwater flow in. The 
$\mathrm{pH}$, electrical conductivity (EC), oxidation-reduction potential (ORP), dissolved oxygen (DO) and temperature of the water samples were measured with portable meters (HORIBA) at sampling site. Four samples were taken at each piezometer after the recovery of water level. Water samples for major ions analysis were initially filtrated through a $0.45 \mu \mathrm{m}$ membrane filter and then collected in a pre-clean $15 \mathrm{ml}$ plastic bottle, and stored at $4{ }^{\circ} \mathrm{C}$ until analysis. For the analysis of dissolved methane, a precleaned $25 \mathrm{ml}$ glass vial was filled with unfiltered water, capped under water, and preserved by adding a drop of bactericide at the sampling site and kept chilled with ice until delivered to the laboratory. To analyze $\mathrm{Fe}^{2+}$ in the groundwater, unfiltered fresh water was taken into a preclean $100 \mathrm{ml}$ plastic bottle and then $1 \mathrm{ml}$ o-phenanthroline solution was added before sealing the bottle at site.

The brown glass bottles of $100 \mathrm{ml}$ were pre-cleaned by burning at $450{ }^{\circ} \mathrm{C}$ for $2 \mathrm{~h}$ to prevent contamination and then used for sampling CFCs. To take sample from the piezometers, the bottles were set into the water sampler that was an air-tight stainless container with a copper inlet and an outlet of nylon tube. The sampler was set at the bottom of piezometer, the fresh groundwater was allowed to flow gently from the inlet into the bottom of glass bottle and push out of air through the outlet before sealing the bottle under water by the cap with Al liner (IAEA 2006; Busenberg and Plummer 2000). It ensured the sample was taken without contamination by the ambient air.

\section{Analytical techniques}

All water samples were analyzed in the Laboratory of Graduate School of Horticulture, Chiba University. Blanks and appropriate certified standard reference materials were analyzed as unknowns. Major ions were determined by ion chromatography (LC-10AS, Shimazu) Methane gas was measured by a gas chromatography (GC-14B, Shimadzu) equipped with a flame ionization detector (FID) with a reproducibility of about $\pm 2 \%$. $\mathrm{Fe}^{2+}$ was measured by spectrophotometer (TU1810, Beijing Tuopu Instrument Co., Ltd.) according to o-phenanthroline spectrophotometric method with detection limit of $0.03 \mathrm{mg} / 1$.

The CFCs in water samples were collected and purified by a purge and trap extraction system (Bullister and Weiss 1988; Oster et al. 1996). The CFCs analytical system was composed mainly of devices of purging, trapping and analyzing. In the system, the ultrapure $\mathrm{N}_{2}$ was used as purging and carrier gas. To avoid contamination and to reduce noise of system background, all devices were made without any plastics, and the valves were in purge housings flushed with carrier gas. First, the sample was introduced into a stripping chamber, and the CFCs were purged with ultrapure $\mathrm{N}_{2}$ and quantitatively collected in a trap (A $35 \mathrm{~cm}$ long, 1/8 steel use stainless (SUS) pipe, filled with Res-sil $\mathrm{C}$ and Porapak T) cooled at $-40{ }^{\circ} \mathrm{C}$ by a refrigerant mixture of methanol and dry ice. Then the trap should be heated to $95{ }^{\circ} \mathrm{C}$ in the hot water to let the CFCs be injected into the gas chromatography through pre-column and analytical column in sequence by carrier gas. CFCs can be separated from other halocarbons in the pre-column. After CFCs entered the analytical column, the pre-column was back flushed to remove all other highly retentive halocarbons. The purified CFCs are analyzed by a gas chromatograph (GC-14B, Shimadzu) equipped with an electron capture detector (ECD). After analysis has been completed, the water sample is drained into a pre-weighed beaker and then weighed for the calculation of CFCs concentration which is reported in $\mathrm{pmol} / \mathrm{kg}$ of water. The uncertainties for CFCs determinations are approximately $1 \%$ for water equilibrated with the ambient atmosphere.

\section{Groundwater dating based on $\mathrm{CFCs}$}

With regard to groundwater dating with CFCs, it is assumed that the local historical CFCs composition of air is known, which is closely followed by the composition of unsaturated zone air. Then, the recharge year can be determined by comparing the calculated partial pressure of CFCs in solubility equilibrium of the water sample with historical CFCs concentration in local air (Plummer et al. 2006). Also, the CFCs age-dating technique assumed that CFCs concentrations in the aquifer have not been altered by biological, geochemical, or hydrologic processes. CFCs apparent ages of groundwater are determined on the basis of the equilibrium partitioning between recharging ground water and the partial pressures of $\mathrm{CFC}-11\left(\mathrm{CCl}_{3} \mathrm{~F}\right), \mathrm{CFC}-12$ $\left(\mathrm{CCl}_{2} \mathrm{~F}_{2}\right)$ and $\mathrm{CFC}-113\left(\mathrm{C}_{2} \mathrm{Cl}_{3} \mathrm{~F}_{3}\right)$ in the troposphere or soil atmosphere. Therefore, concentration of CFCs in groundwater is the function of atmospheric partial pressures and temperature during recharge. An apparent age of the sampled water is determined from a comparison of the partial pressure of each CFCs compounds in the sample, calculated from its measured concentration using solubility data for each compound, with the record of atmospheric partial pressures over North America at different times. Concentrations of the three CFCs compounds ideally provide three independent ages, which can be used as a crosscheck on the sampling and analytical methods.

Groundwater dating with CFCs is based on Henry's law solubility. That is, the concentration of the gas dissolved in water in equilibrium with air is proportional to the partial pressure $\left(p_{i}\right)$ of the gas in air.

$p_{i}=x_{i}\left(\mathrm{P}-p_{\mathrm{H}_{2} \mathrm{O}}\right)$

where $x_{i}$ is the dry air mole fraction of the CFCs $\left(x_{i} \ll 1\right)$; $\mathrm{P}$ is the total atmospheric pressure and $\mathrm{p}_{\mathrm{H} 2 \mathrm{O}}$ is the water 
vapor pressure. For an ideal gas, the dry air mole fraction is replaced with the air mixing ratio. Henry's law then gives the CFCs solubility in water $\left(C_{\mathrm{i}}\right)$.

$C_{i}=K_{\mathrm{H}_{i}} \times p_{i}$

where $K_{\mathrm{H} i}$ is the Henry's law coefficient for the $i$ th CFC, which in pure water and sea water have been determined at 1,013.25 hPa total pressure over a range of salinities and temperatures (Warner and Weiss 1985; Bu and Warner 1995). The dry air mixing ratio for the particular CFCs $\left(x_{i}\right)$ is then compared to the appropriate historical atmospheric mixing ratio to determine recharge year.

\section{Binary mixture based on CFCs}

Provided the CFCs in groundwater are in equilibrium with the air during recharge period, the difference in the measured apparent ages estimated by CFCs should be the result of the mixture of groundwater in the aquifer. Therefore, it is important to identify the water mixing processes to get useful information for hydrological investigations. The measured concentrations of tracers (CFCs) in the mixture of two waters with different ages can be explained by the following equations:

$[\operatorname{tracer} 1]_{\mathrm{mix}}=(1-x)[\operatorname{tracer} 1]_{z}+x[\operatorname{tracer} 1]_{y}$

$[\operatorname{tracer} 2]_{\operatorname{mix}}=(1-x)[\operatorname{tracer} 2]_{z}+\mathrm{x}[\text { tracer } 2]_{y}$

where $x(0<x<1)$ is the fraction of the young groundwater; $y$ is the concentration of tracer in the young groundwater; $z$ is the concentration of tracer in the old groundwater. Based on the historical concentrations of CFCs in the North atmosphere, there should be many solutions for probable mixing between old groundwater and young groundwater in Eqs. (3) and (4). It can be summarized as following:

(a) When tracer-free water (before 1940) exists, Eq. (5) can be found by combination Eqs. (3) and (4):

$\frac{[\operatorname{tracer} 1]_{\mathrm{mix}}}{[\operatorname{tracer} 2]_{\mathrm{mix}}}=\frac{[\operatorname{tracer} 1]_{y}}{[\operatorname{tracer} 2]_{y}}$

Using the Eq. (5), a quantitative calculation of the mixing fraction can be performed easily when the binary mixing with one end member is basically CFC-free, it has been used in many reported studies solving a number of practical hydrological problems (Gooddy et al. 2006; Han et al. 2012; Han et al. 2007). But for binary mixtures in which both of the end members contain CFCs, the estimation of water ages and calculation of mixing fractions are more complicated, though mathematically possible.

(a) When the groundwater was recharged after 1940s, it is reasonable to consider that the most possible end members for mixing in an aquifer are the groundwaters, of which the age difference should be the smallest. Therefore, the constraint condition $\varepsilon$ associated Eqs. (3) and (4) is as the following.

$\varepsilon=\min \{|\operatorname{age}([\operatorname{trace} 1] y)-\operatorname{age}([\operatorname{tracer} 2] z)|\}$

As usual, the groundwater along the flow path nearby has a similar recharge condition and flow pattern in the aquifer.

\section{Results}

Characteristic of groundwater flow within the wetland

Groundwater plays a key role in maintaining wetland ecosystem. Therefore, characteristic of groundwater flow system is very important for studies in the wetland basin. As a whole, the water table of groundwater in piezometers changed little during the study period. The hydraulic heads of groundwater at three sites (S6, R2 and S15) increased from 1 to $3 \mathrm{~m}$ (Fig. 2), indicating that groundwater was upward in the studied wetland. According to the landform of the valley, groundwater should flow out as springs at the slope foot adjacent to the wetland, or seep directly at the wetland surface, indicating that the wetland was maintained by groundwater or spring.

The parameters of groundwater in piezometers

The $\mathrm{pH}$ and EC ranged from 6.48 to 7.72 , and from 235 to $981 \mu \mathrm{S} / \mathrm{cm}$, with the average of 7.36 and $470 \mu \mathrm{S} / \mathrm{cm}$, respectively. DO varied from 0.13 to $4.45 \mathrm{mg} / \mathrm{l}$ with a mean value of $2.00 \mathrm{mg} / \mathrm{l}$ (Table 1). Denitrification was prevailing in the wetland aquifers after the DO content was at a low level. As a result, $\mathrm{NO}_{3}{ }^{-}$concentration varied highly from the undetectable to $5.75 \mathrm{mmol} / \mathrm{l}$, depending on the reduction condition for denitification in the wetland. The concentrations of $\mathrm{SO}_{4}{ }^{2-}$ and $\mathrm{Fe}^{2+}$ in groundwater ranged from undetectable to $0.31 \mathrm{mmol} / \mathrm{l}$, and from undetectable to $42.14 \mu \mathrm{mol} / 1$, respectively. $\mathrm{CH}_{4}$ was also detected in a range from undetectable to $0.32 \mathrm{mmol} / \mathrm{l}$ because of development of reducing condition in the wetland.

Spatially, the characteristics of groundwater parameters at the valley side (S6 and S15) were different from that in the middle part (R2) of the wetland. At the valley side, the values of $\mathrm{pH}, \mathrm{DO}$ and ORP ranged from 6.48 to 7.25 , from 1.67 to $4.45 \mathrm{mg} / \mathrm{l}$ and from 86 to $198 \mathrm{mV}$, respectively. The concentrations of $\mathrm{NO}_{3}{ }^{-}$and $\mathrm{SO}_{4}{ }^{2-}$ varied from 0.26 to $5.75 \mathrm{mmol} / \mathrm{l}$ and from 0.01 to $0.12 \mathrm{mmol} / \mathrm{l}$, respectively. $\mathrm{Fe}^{2+}$ and $\mathrm{CH}_{4}$ were not detectable from the piezometers at valley sides. 


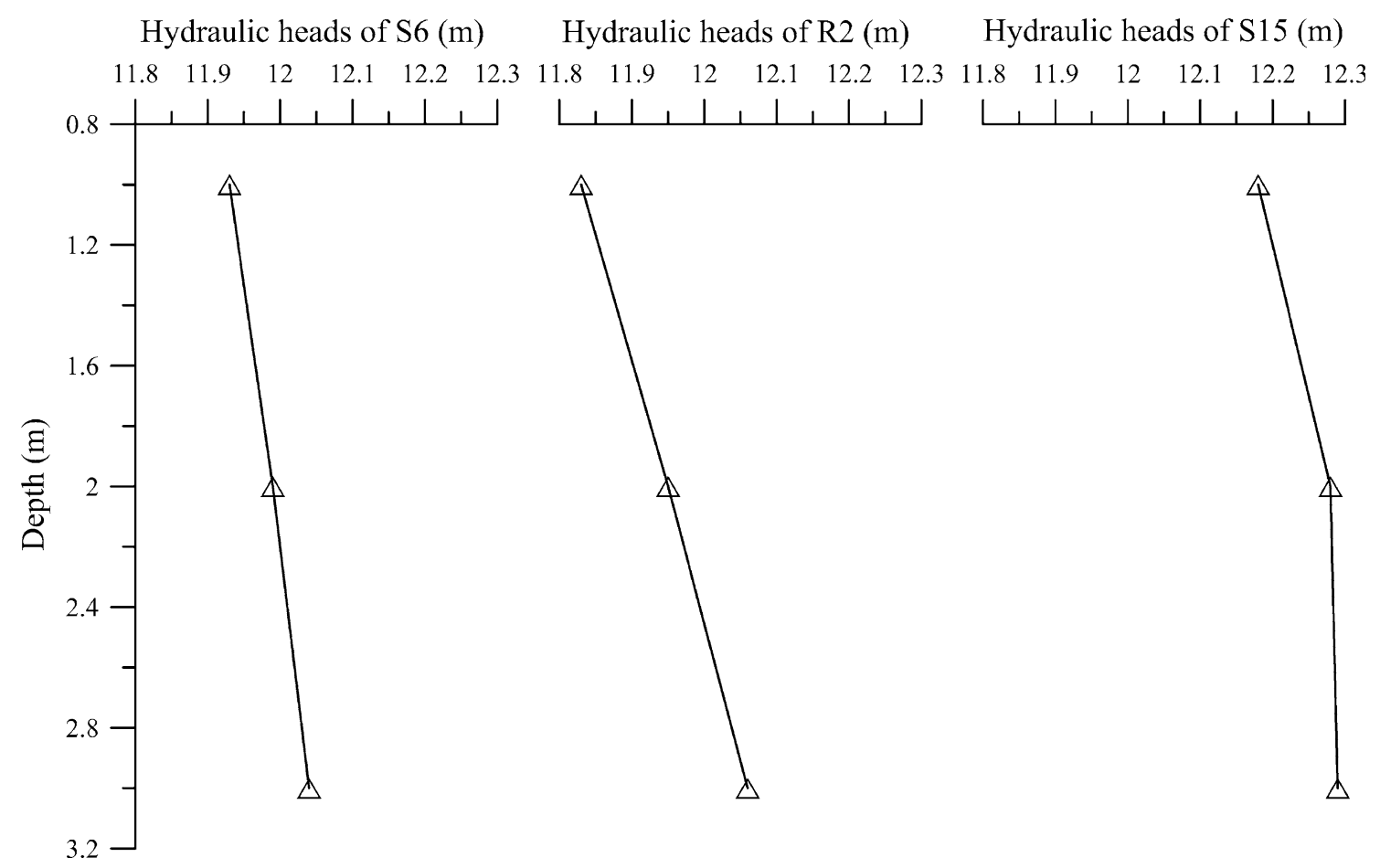

Fig. 2 The characteristics of hydraulic head of S6, R2 and S15 in the wetland

Table 1 Parameters in groundwater of piezometers at R2, S6 and $\mathrm{S} 15$ in the wetland

\begin{tabular}{llllc}
\hline ID $(\mathrm{m})$ & $\mathrm{pH}$ & $\mathrm{EC}(\mu \mathrm{S} / \mathrm{cm})$ & $\mathrm{DO}(\mathrm{mg} / \mathrm{l})$ & ORP $(\mathrm{mV})$ \\
\hline R2-1 & 7.15 & 264 & 0.14 & -26 \\
R2-2 & 7.47 & 260 & 0.13 & -189 \\
R2-3 & 7.72 & 248 & 0.68 & -244 \\
S6-1 & 7.25 & 299 & 3.30 & 86 \\
S6-2 & 6.60 & 765 & 2.00 & 185 \\
S6-3 & 6.48 & 981 & 1.67 & 198 \\
S15-1 & 7.01 & 235 & 4.45 & 172 \\
S15-2 & 6.78 & 681 & 2.42 & 169 \\
S15-3 & 6.86 & 495 & 3.25 & 176 \\
\hline
\end{tabular}

In the middle part of the wetland (R2), the values of $\mathrm{pH}, \mathrm{DO}$ and ORP ranged from 7.15 to 7.72 , from 0.13 to $0.68 \mathrm{mg} / \mathrm{l}$ and from -26 to $-244 \mathrm{mV}$, respectively. The concentrations of $\mathrm{NO}_{3}{ }^{-}$and $\mathrm{SO}_{4}{ }^{2-}$ ranged $0-0.01$ and $0.01-0.31 \mathrm{mmol} / \mathrm{l}$, respectively. $\mathrm{Fe}^{2+}$ of groundwater ranged from the undetectable to $42.14 \mu \mathrm{mol} / \mathrm{l}$. The dissolved $\mathrm{CH}_{4}$ of groundwater ranged from the undetectable to $0.32 \mathrm{mmol} / \mathrm{l}$.

\section{Concentrations of CFCs in the groundwater}

To determine groundwater age, it is necessary to estimate recharge temperature and elevation. The groundwater of studied wetland is recharged by the precipitation available in the upland. The upland elevation of $30 \mathrm{~m}$ above sea level was used to estimate the change of total atmospheric pressure $(p)$ in the recharge area. In this study, the mean annual air temperature of $14.8{ }^{\circ} \mathrm{C}$ was assumed as the recharge temperature (Liu et al. 2012; Han et al. 2012). Accordingly, the apparent groundwater age based on the analyzed data of CFC-11, CFC-12 and CFC-113 are shown in Table 2.

The apparent groundwater ages by CFC-11, CFC-12 and CFC-113 at R2 were ranging from 1958.5 to 1960 , from 1950.5 to 1973 and from 1943 to 1977.5 , respectively. At the two sides of the wetland valley, the apparent groundwater ages by CFC-11, CFC-12 and CFC-113 were varied from 1956.5 to 1973, from 1963 to 1971 and from 1970 to 1982, respectively. Obviously, the apparent groundwater age in the middle part of the wetland was older than those at the valley sides. Averagely, the groundwater age in the depth of $1 \mathrm{~m}$ was older than that in the below depth. However, the apparent groundwater ages were different with the different species of CFCs in the study area. Therefore, more attentions should be paid on the environment conditions of wetland and the way to estimate the groundwater age by CFCs, which would be discussed below.

\section{Discussion}

The effect of reducing environment on CFCs

Based on principles of CFCs dating technique, whether the apparent age information can be applied to the water in which the tracers are dissolved depends on how completely 
Table 2 Calculated atmospheric mixing ratio, piston-flow model recharge year, corresponding piston-flow model apparent ages and the recommended apparent ages of CFC-11, CFC-12 and CFC-113 for the groundwater samples

\begin{tabular}{|c|c|c|c|c|c|c|c|c|c|c|}
\hline \multirow[t]{2}{*}{ ID (m) } & \multicolumn{3}{|c|}{$\begin{array}{l}\text { Calculated atmospheric } \\
\text { mixing ratio (pptv) }\end{array}$} & \multicolumn{3}{|c|}{$\begin{array}{l}\text { Piston-flow model } \\
\text { recharge year }\end{array}$} & \multicolumn{3}{|c|}{$\begin{array}{l}\text { Piston-flow model apparent } \\
\text { age (years) }\end{array}$} & \multirow{2}{*}{$\begin{array}{l}\text { Recommended } \\
\text { apparent age } \\
\text { (years) }\end{array}$} \\
\hline & CFC-11 & CFC-12 & CFC-113 & CFC-11 & CFC-12 & CFC-113 & CFC-11 & CFC-12 & CFC-113 & \\
\hline R2-1 & 8.75 & 8.35 & 0 & 1958.5 & 1950.5 & Pre-1940 & 52.5 & 60.5 & $>60$ & - \\
\hline R2-2 & 10.41 & 171.66 & 17.04 & 1960 & 1972 & 1977.5 & 51 & 39 & 33.5 & 39 \\
\hline R2-3 & 9.6 & 182.48 & 5.66 & 1959.5 & 1973 & 1969.5 & 51.5 & 38 & 41.5 & 38 \\
\hline S6-1 & 31.54 & 160.08 & 7.56 & 1966 & 1971.5 & 1972 & 45 & 39.5 & 39 & 39 \\
\hline S6-2 & 5.46 & 169.42 & 6.22 & 1956.5 & 1972 & 1970.5 & 54.5 & 39 & 40.5 & 39 \\
\hline S6-3 & 52.74 & 135.78 & 19.41 & 1969 & 1970 & 1978.5 & 42 & 41 & 32.5 & 43.5 \\
\hline S15-1 & 80.24 & 109.22 & 22.28 & 1972 & 1968.5 & 1979.5 & 39 & 42.5 & 31.5 & 42.5 \\
\hline S15-2 & 14.89 & 54.77 & 32.02 & 1962 & 1963 & 1982.5 & 49 & 48 & 28.5 & 48 \\
\hline S15-3 & 90.49 & 146.71 & 13.66 & 1973 & 1971 & 1976 & 38 & 40 & 35 & 40 \\
\hline
\end{tabular}

the tracers are transported with the water. There are many processes associated with CFCs migration in the groundwater environment. If these processes are not recognized properly, the interpretation of the CFCs age of a water sample will be appreciably affected.

Although the processes that can affect the interpretation of CFCs age have been investigated and quantified to some extent, dominated processes are still unclear at the site. The reliable interpretation of groundwater age by CFCs depends on the available information that can help characterize the geochemical and hydrological environment in field. In general, the concentrations of CFCs can be affected by recharge temperature, recharge elevation, thickness of unsaturated zone $(>10 \mathrm{~m})$, urban air, contamination, microbial degradation, adsorption or diffusion in groundwater, groundwater mixtures and hydrodynamic dispersion in the aquifers (Plummer and Busenberg 2000). Depending on whether the recharge temperature, excess air and recharge elevation is underestimated or overestimated, the resulting apparent age can be biased either young or old. The addition of anthropogenic sources of CFCs, concentrations greater than that expected for equilibrium with regional air composition, leads to a young bias in apparent age. Processes that remove CFCs or lower their concentration in groundwater, such as microbial degradation, sorption, mixing with old water, thickness of unsaturated zone $(>10 \mathrm{~m})$, matrix diffusion and some cases of hydrodynamic dispersion, can lead to an old bias in the apparent age (Plummer and Busenberg 2000).

As mentioned in the part of results, the groundwater was recharged by the precipitation in the upland around the wetland valley. Therefore, the upland elevation of $30 \mathrm{~m}$ was used as the recharge elevation of groundwater in the wetland. Where the unsaturated zone is more than a few meters thick, the variation of recharge temperature is usually within about $1{ }^{\circ} \mathrm{C}$ comparing with the mean annual air temperature (Mazor 1972; Andrews and Lee 1979; Herzberg and Mazor 1979; Vogel and Talma 1981; Toy and Munson 1978). Consequently, the mean annual air temperature $\left(14.8{ }^{\circ} \mathrm{C}\right)$ is reasonable as the air-water equilibrium temperature for calculating CFCs age in the study area. In spite of the change of land use in last several decades, there has not been industrialization in the study area. As a result, the concentrations of CFCs are in the normal level without the effects of extra anthropogenic sources.

The water table is as shallow as $8 \mathrm{~m}$ where the strata are mainly composed of Narita sand layer. Consequently, there should be little effect of sorption, matrix diffusion, and hydrodynamic dispersion in the unsaturated zone on the concentrations of CFCs in groundwater (IAEA 2006). Therefore, the processes of microbial degradation and mixing are important for groundwater dating in the wetland.

Under aerobic conditions, the apparent ages estimated by CFC-11, CFC-12 and CFC-113 demonstrate agreement with each other, and match well with data by other environmental tracers (Katz et al. 1995; Plummer et al. 1998; Dunkle et al. 1993; Szabo et al. 1996). Although CFC-11, CFC-12 and CFC-113 may be considered essentially stable under aerobic conditions (Rowland and Molina 1975; Lovley and Woodward 1992), they are subject to degradation processes under anaerobic conditions (Lovley and Woodward 1992; Khalil and Rasmussen 1989; Semprini et al. 1992). It is well known that reductive status can proceed because of microbial degradation in the wetland environment.

The effect of reductive condition on CFCs is discussed consequently. Field and laboratory studies have shown that CFC-11 is the most degradable among the three CFCs (CFC-12, CFC-11 and CFC-113). Cook et al. (1995) demonstrated that CFC-11 was degraded completely but 
CFC-12 was still stable in a sulfate reducing sand aquifer near Sturgeon Falls, Ontario, Canada. Under methanogenic condition, CFC-11 was degraded with an average rate nearly 37-fold. Although CFC-12 and CFC-113 also decomposed under methanogenic condition, the degradation rate of CFC-12 and CFC-113 are more slowly than that of CFC-11.

In the viewpoint of reduction status proceeding in the wetland, there are denitrifying condition, sulfidogenic condition and methanogenic condition. In general, when denitrification takes place in the aquifer, CFC-12 and CFC113 apparent ages can be identical and younger than CFC11 apparent age because of the partially degradation of CFC-11. Under sulfidogenic condition, CFC-11 is highly degraded, CFC-113 begins to decompose and CFC-12 is still stable. As a result, CFC-113 apparent age can be a few years older than $\mathrm{CFC}-12$ under sulfidogenic condition. If methanogenic condition is present in the aquifer, CFCs will not be suitable for groundwater dating because all of them can be degraded in most methanogenic environments (Plummer and Busenberg 2000; Horneman et al. 2008; Happell et al. 2003).

In the wetland, it is obviously that the $\mathrm{NO}_{3}{ }^{-}$is decreasing in the upward groundwater, and $\mathrm{Fe}^{2+}$ is undetectable in all groundwaters at S6 and S15 (Fig. 3). In addition, the ORP of groundwater at S6 and S15 are below $200 \mathrm{mV} . \mathrm{NO}_{3}{ }^{-}$is undetectable in the aquifer at R2 where $\mathrm{SO}_{4}{ }^{2-}$ is decreasing. Meanwhile, both of $\mathrm{Fe}^{2+}$ and $\mathrm{CH}_{4}$ increase with the upward groundwater from 3 to $1 \mathrm{~m}$ in depth (Fig. 4). Based on the classification of redox condition (Appelo and Postma 2005; Berner 1981), the groundwater in piezometers at S6 and S15 is under denitrifying condition. Correspondingly, CFC-11 apparent ages of groundwater at S6 and S15 are older than those of CFC12 and CFC-113, indicating that CFC-11 cannot be used for groundwater dating because of the degradation in the wetland aquifer (Fig. 5). Instead, CFC-12 and CFC-113 can be used for groundwater dating at S6 and S15. Correspondingly, the sulfidogenic condition and/or methanogenic condition which are prevailing in the aquifers at R2 are more reductive than the denitrifying condition. CFC-11 at R2 is also not suitable for groundwater dating with the apparent age of CFC-11 older than those of CFC-12 and CFC-113 (Fig. 6). Comparing with the groundwater in the depths of 2 and $3 \mathrm{~m}$, the apparent ages of CFC-12 and CFC-113 of groundwater in the depth of $1 \mathrm{~m}$ are much older (Fig. 6), where $\mathrm{CH}_{4}$ concentration is highest in groundwater at R2 (Fig. 4). Based on the principles of CFCs dating, the old CFCs apparent ages indicate the low concentration of CFCs in the groundwater under the given recharge temperature. The obviously lower concentration of CFC-12 and CFC-113 in groundwater of $1 \mathrm{~m}$ in depth can be attributed to the degradation of CFCs in

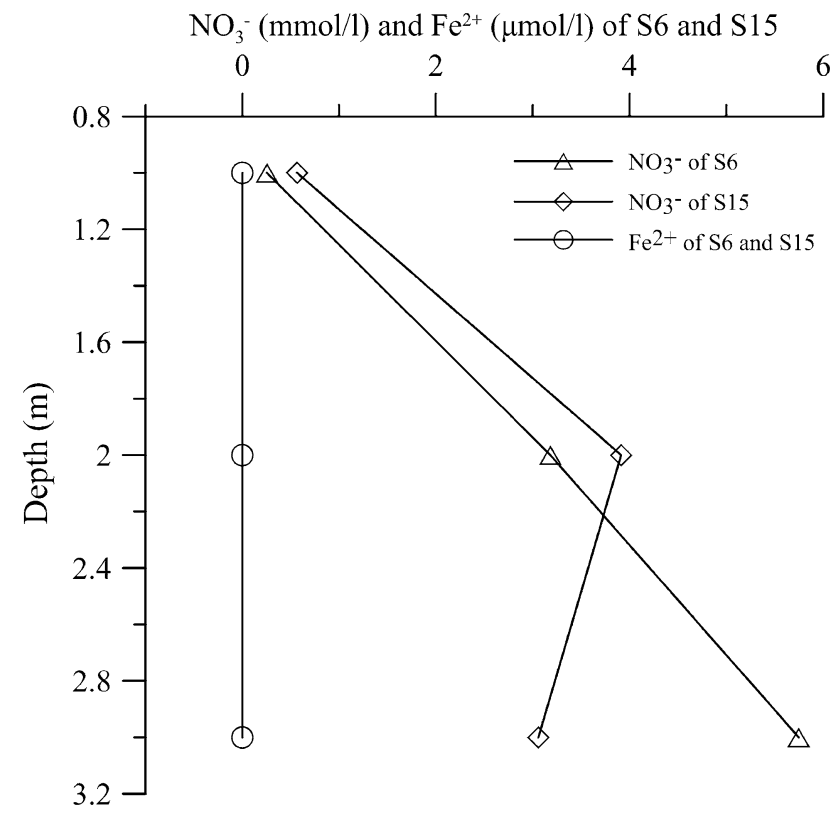

Fig. 3 The concentration of $\mathrm{NO}_{3}{ }^{-}$and $\mathrm{Fe}^{2+}$ in groundwater of S6 and $\mathrm{S} 15$

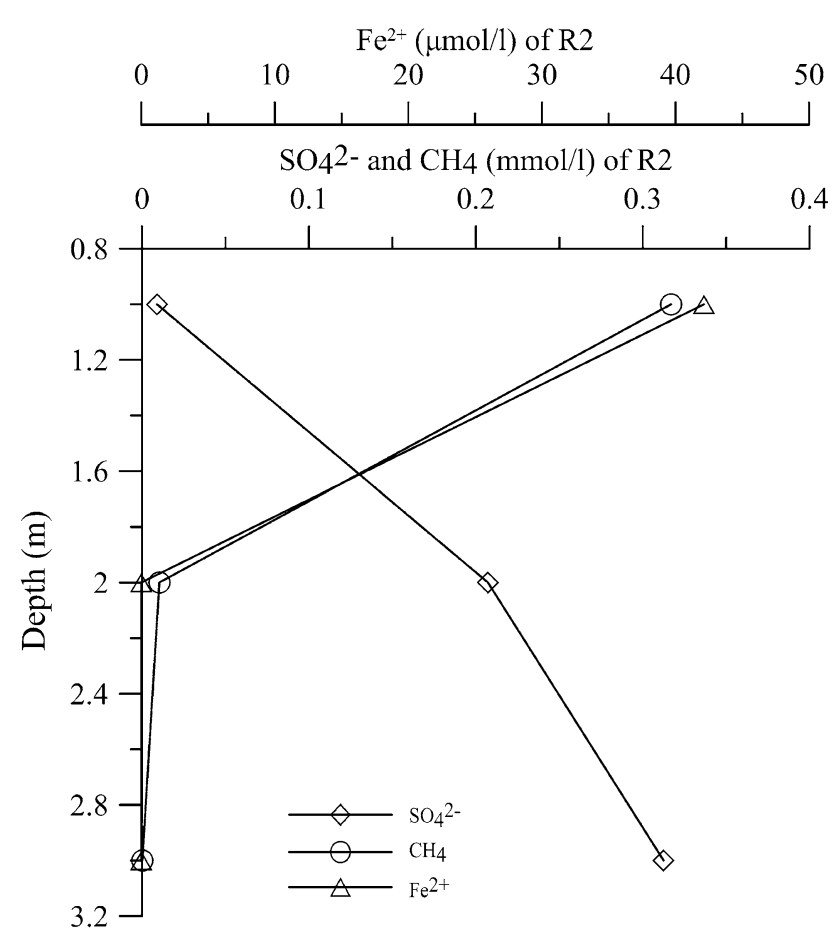

Fig. 4 The distribution of redox species $\left(\mathrm{SO}_{4}{ }^{2-}, \mathrm{Fe}^{2+}\right.$ and $\left.\mathrm{CH}_{4}\right)$ in groundwater of 1,2 and $3 \mathrm{~m}$ at R2

groundwater undergoing methanogenic environment. Therefore, all CFCs in groundwater from the $1 \mathrm{~m}$ depth piezometer at R2 cannot be used for groundwater dating. Since groundwater of piezometers in 2 and $3 \mathrm{~m}$ is under the sulfidogenic condition, CFC-12 rather than CFC-113 is stable enough for groundwater dating. 


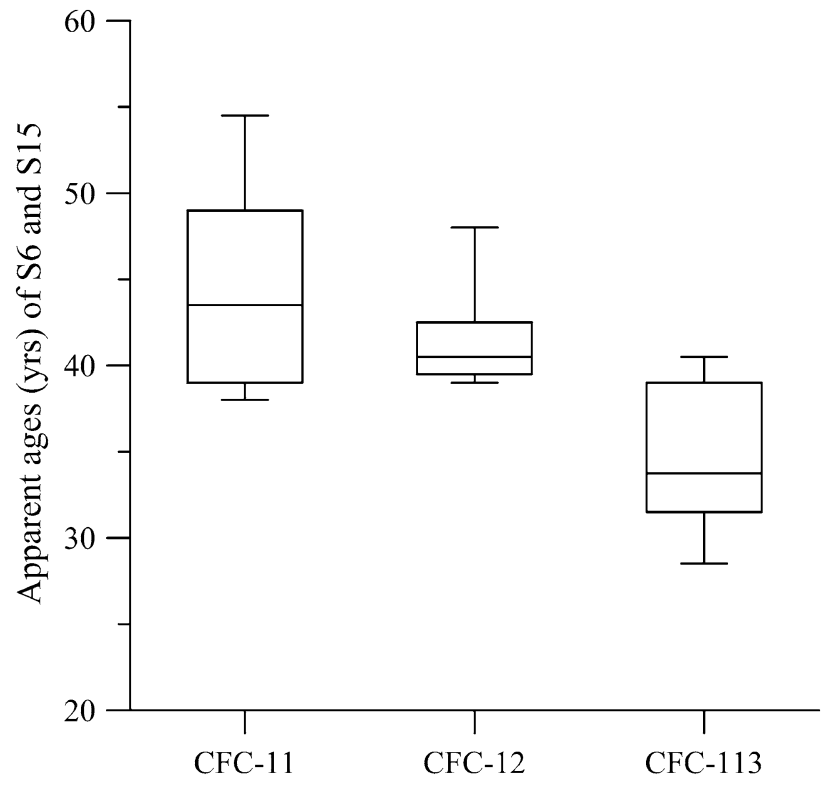

Fig. 5 The apparent age based on CFCs of S6 and S15

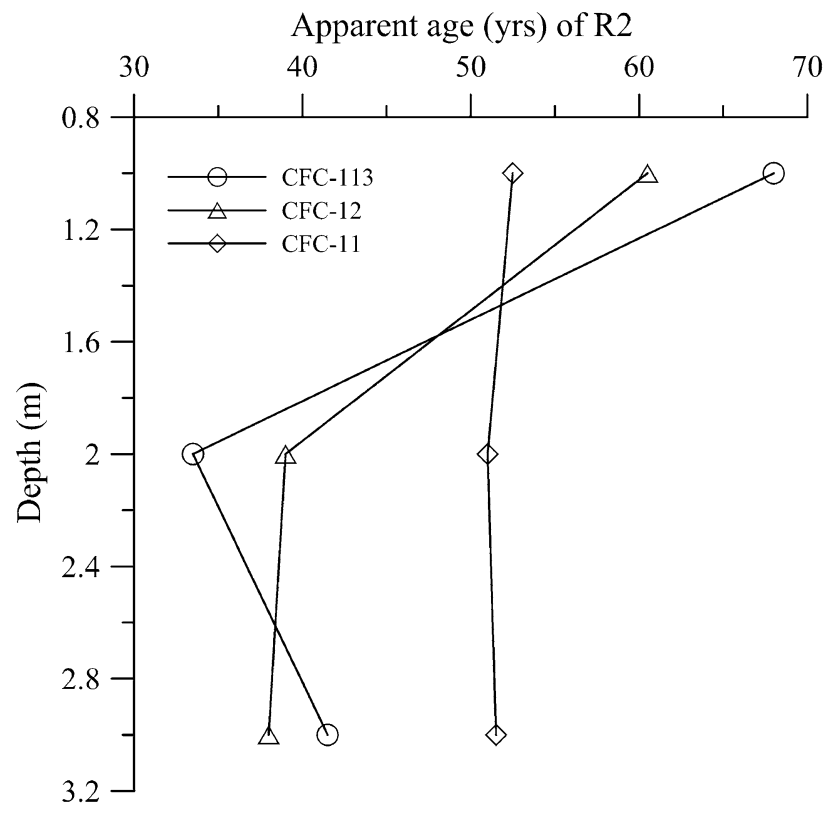

Fig. 6 The characteristic of apparent ages of CFCs (CFC-11, CFC-12 and CFC-113) in middle of wetland (R2)

As a whole, in terms of groundwater dating, CFC- 11 is unsuitable in the study area where groundwater is undergoing reduction environment from denitrifying condition to methanogenic condition, CFC-113 can work at S6 and S15 where groundwater is under denitrifying condition, and CFC-12 is useful in all points except for the $1 \mathrm{~m}$ depth piezometer at R2 where groundwater is under methanogenic condition.
Groundwater age estimated by CFC-12 and CFC-113

Groundwater pumped from a well or discharging from a spring may be a mixture of the different waters reaching the sampling point. Piston flow, exponential mixing, exponential piston flow, and binary mixing are hypothetical models that can be used to describe the variation in groundwater mixtures (Cook and Böhlke 2000). If water reaching a well or discharging at a spring is nearly uniform residence time as if the water flowed through a pipe from recharge area to discharge area without mixing during transit, it can be considered as piston-flow model (PFM). Exponential mixing model (EMM) can be described as discharge of water from wellmixed reservoirs, such as discharge from an unconfined aquifer receiving uniform areal recharge (Małoszewski and Zuber 1982; Małoszewski et al. 1983). The exponential piston-flow model (EPM) can be used to describe an aquifer that has two segments of flow in series: a segment of exponential flow followed by a segment of piston-flow (Jurgens et al. 2012).

Binary mixing model (BMM) is one of the simplest mixing models dealing with the mixing processes between young water and old water. If the old fraction is free of CFCs, and no other processes affect their concentrations other than air-water equilibrium, the ratio CFC-113/CFC12 may be proved useful in dating mixtures of young and old water. Once the age of the young fraction is determined, the proportion of young water in the mixture can be determined from the ratio of the tracer concentration of the sample to the concentration expected for an unmixed sample of age corresponding to the young-fraction age.

In Fig. 7, the area bounded by PFM and BMM is defined as zone A. As a result, the zones of A, B, C, D, E and F represent the processes of binary mixing or piston flow in zone A, most likely CFC-113 contamination in zone B, CFC-12 contamination or CFC-113 sorption/degradation in zone $\mathrm{C}, \mathrm{CFC}-113$ contamination in zone $\mathrm{D}, \mathrm{CFC}-12$ contamination in zone E, and CFC-113 and CFC-12 contamination in zone F, respectively (IAEA 2006). If no other processes affected, measured values for water samples will plot within the zone A, where the curves represent the different concentrations of the modeled tracers. A water sample that is not a mixture should plot along the piston flow (solid) curve for two tracers at points corresponding to the single age of the water. Samples in zone A that do not plot on the piston-flow curves are more likely to represent mixtures. An exponential mixture and EPM should plot somewhere along homologous curves at points corresponding to a single mean age. Binary mixtures could plot almost anywhere within the zone A depending on the ages of the end members.

It is obvious that groundwater in the depth of $3 \mathrm{~m}$ at both $\mathrm{S} 6$ and S15 are probable a mixture of groundwaters that is 


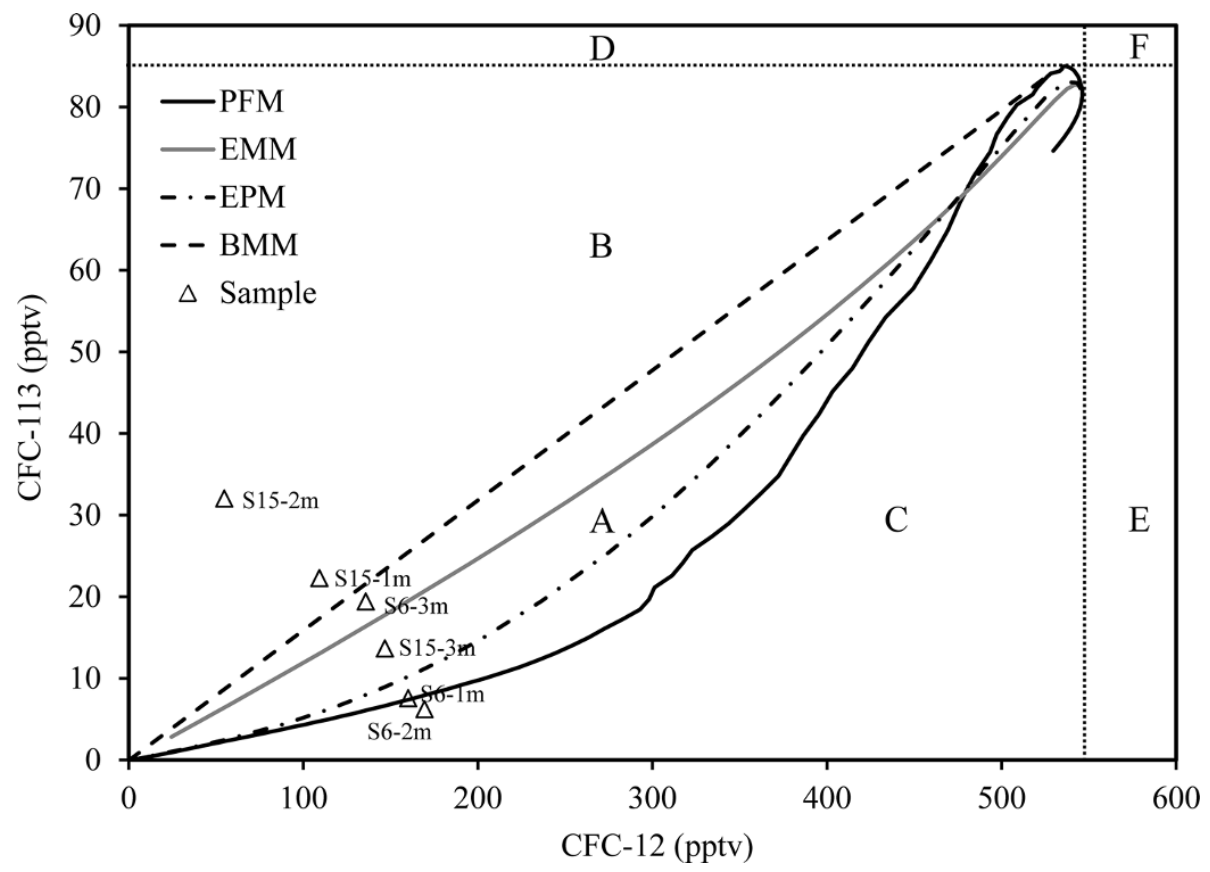

Fig. 7 Relation between CFC-12 and CFC-113 mixing ratio in air (pptv) of age-dating tracers in the study area. Plots are shown as curves corresponding to different groundwater mixing models: (1) solid line indicates compositions of discrete water parcels with single ages (corresponds to the piston-flow model); (2) gray line indicates compositions of mixtures with exponential age distributions (exponential mixing model); (3) long-short dashed line indicates an aquifer that has two segments of flow in series: a segment of exponential flow

reasonable to be explained by binary mixing flow model, because the data plot away from exponential mixture curve and exponential piston-flow curve (Fig. 7). The groundwaters shallower than $2 \mathrm{~m}$ at $\mathrm{S} 6$ can be considered as piston flow since the data are on or close to the curve of PFM. However, the data of groundwater shallower than $2 \mathrm{~m}$ at S15 fall in the zone B. The higher concentration of CFC-113 or lower concentration of CFC-12 can be attributed to the contamination of CFC-113 or the degradation of CFC-12. Because CFC-12 cannot be degraded under denitrifying condition in groundwater, it is reasonably due to the contamination of CFC- 113 . When the calculated CFC partial pressures exceed the maximum mixing ratios observed in the atmosphere, significant contamination with respect to one or more CFCs will be evident (zone F). However, there is also uncertainty about samples that may be only slightly contaminated, but the apparent age is still in the valid "dating range" which cannot be calculated precisely. The CFC-113 in the groundwater shallower than $2 \mathrm{~m}$ at $\mathrm{S} 15$ should be this kind of situation, and the precise ages cannot be obtained with the mixing flow concept. Sometimes, cases of low level contamination result from local enrichment in air composition or through some land use practices that occur over broad regions (IAEA 2006).

For binary mixing flow, calculation of mixing fractions is more complicated mathematically. In terms of followed by a segment of piston flow (exponential piston-flow model). (4) Dashed lines indicate maximum boundaries of probable binary mixtures between young water and old water (binary mixing model). The zones of $A, B, C, D, E$ and $F$ represent the processes of binary mixing or piston flow, most likely CFC-113 contamination, CFC-12 contamination or CFC-113 sorption, CFC-113 contamination, CFC-12 contamination, and CFC-113 and CFC-12 contamination (IAEA 2006)

probability mentioned in the method section of this paper, the mixture of two end members which ages have the minimum difference is the most possible result for the groundwater of the study area. Accordingly, the groundwater in the depth of $3 \mathrm{~m}$ at S6 and S15 are mixtures of groundwater recharged in 1957 and 1994 with the old groundwater proportion of $28.30 \%, 1965$ and 1986 with the old groundwater proportion of $28.47 \%$, respectively (Fig. 8). Therefore, the apparent mean ages of groundwater $3 \mathrm{~m}$ in depth are 43.5 years at $\mathrm{S} 6$ and 40 years at S15, respectively (Table 2 ).

As a piston flow, the recharge period for the groundwater shallower than $2 \mathrm{~m}$ at $\mathrm{S} 6$ is estimated as 1972 (i.e., the groundwater ages are as old as 39 years). With respect to groundwater shallower than $2 \mathrm{~m}$ at S15, the ages cannot be calculated precisely by the mixing flow models described above. Because the feature of landform and strata at two sides in the wetland valley are very similar, the characteristics of groundwater flow at $\mathrm{S} 15$ should be also same as those at S6. Therefore, groundwater shallower than $2 \mathrm{~m}$ at $\mathrm{S} 15$ can be considered as piston flow reasonably. The ages of groundwater can be recommended as the apparent ages of CFC-12 which is credible, in other words, 48 years of $2 \mathrm{~m}$ and 42.5 years of $1 \mathrm{~m}$ at $\mathrm{S} 15$. In addition, CFC-12 is credible under sulfidogenic condition at R2 as described in the 
Fig. 8 The minimum age difference of S6-3 and S15-3 m between young water and old water in the binary mixture model

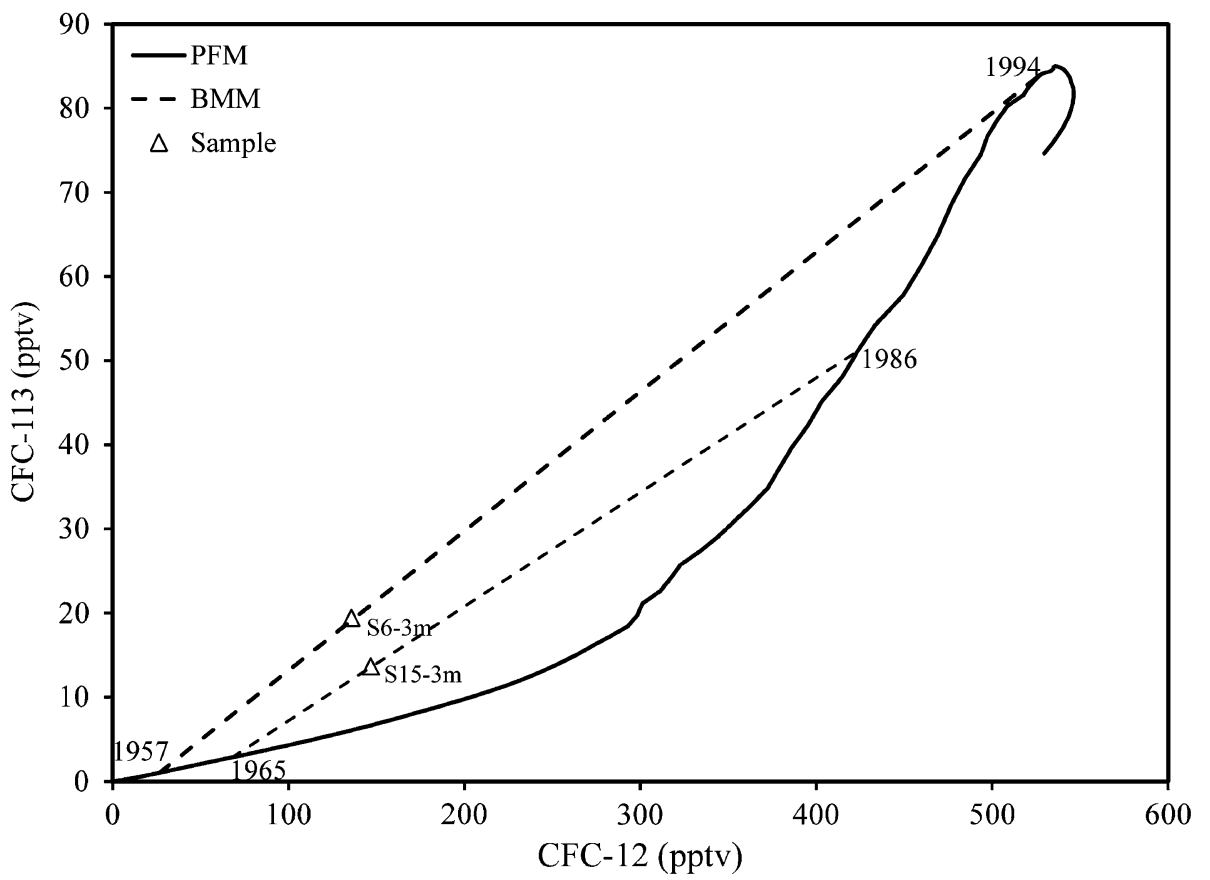

previous section. The CFC-12 apparent ages of groundwater in the depths of 2 and $3 \mathrm{~m}$ at R2 are estimated as 39 and 38 years, respectively. As a whole, groundwater age in the study area is estimated in the range of 38-48 years.

\section{Conclusions}

Generally, redox condition and mixing are the most important factors to estimate applicability of groundwater dating with CFCs in the wetland environment. Based on the spatial distribution of $\mathrm{NO}_{3}{ }^{-}, \mathrm{ORP}, \mathrm{Fe}^{2+}, \mathrm{SO}_{4}{ }^{2-}$ and dissolved $\mathrm{CH}_{4}$ in the wetland, there were reduction status for denitrification, sulfate reduction and methanogen in terms of CFCs degradation. It was found that denitrification environment was prevailing in groundwater at S6 and S15, sulfate reducing environment in the groundwater deeper than $2 \mathrm{~m}$ at $\mathrm{R} 2$ and methanogenic environment at the layer of $1 \mathrm{~m}$ in depth at R2. Therefore, CFC-11 is not suitable for groundwater dating because of biodegradation. CFC- 12 is effective for the groundwater dating in the wetland except the layer $1 \mathrm{~m}$ in depth at $\mathrm{R} 2$ where methanogenic condition is prevailing. $\mathrm{CFC}-113$ is only useful for groundwater dating at S6 and S15 because of the unstability under sulfidogenic and/or methanogenic conditions at R2.

The difference of apparent age between CFC-12 and CFC-113 is attributed to the mixture between young and old groundwater. Among PFM, EMM, EPM and BMM, the BMM and PFM were considered as the most possible flow types in the wetland. As a whole, groundwater age in the wetland was estimated in the range of $38-48$ years.

Open Access This article is distributed under the terms of the Creative Commons Attribution License which permits any use, distribution, and reproduction in any medium, provided the original author(s) and the source are credited.

\section{References}

Alvarado JAC, Purtschert R, Hinsby K, Troldborg L, Hofer M, Kipfer $\mathrm{R}$, Aeschbach-Hertig W, Arno-Synal H (2005) $36 \mathrm{Cl}$ in modern groundwater dated by a multi-tracer approach $(3 \mathrm{H} / 3 \mathrm{He}, \mathrm{SF} 6$, CFC-12 and $85 \mathrm{Kr}$ ): a case study in quaternary sand aquifers in the Odense Pilot River Basin, Denmark. Appl Geochem 20(3):599-609. doi:10.1016/j.apgeochem.2004.09.018

Andrews JN, Lee DJ (1979) Inert gases in groundwater from the Bunter Sandstone of England as indicators of age and palaeoclimatic trends. J Hydrol 41(3):233-252. doi:10.1016/00221694(79)90064-7

Appelo CAJ, Postma D (2005) Geochemistry, groundwater and pollution. 2nd edn. A.A. Balkema Publishers, Amsterdam

Berner RA (1981) A new geochemical classification of sedimentary environments. J Sediment Res 51(2). doi:10.1306/212F7C7F2B24-11D7-8648000102C1865D

$\mathrm{Bu}$ X, Warner MJ (1995) Solubility of chlorofluorocarbon 113 in water and seawater. Deep Sea Res Part I 42(7):1151-1161. doi:10.1016/0967-0637(95)00052-8

Bullister JL, Weiss RF (1988) Determination of $\mathrm{CCl}_{3} \mathrm{~F}$ and $\mathrm{CCl}_{2} \mathrm{~F}_{2}$ in seawater and air. Deep Sea Res Part A Oceanogr Res Papers 35(5):839-853. doi:10.1016/0198-0149(88)90033-7

Busenberg E, Plummer LN (1992) Use of chlorofluorocarbons $(\mathrm{CCl} 3 \mathrm{~F}$ and $\mathrm{CCl} 2 \mathrm{~F} 2)$ as hydrologic tracers and age-dating tools: the alluvium and terrace system of central Oklahoma. Water Resour Res 28(9):2257-2283. doi:10.1029/92WR01263 
Busenberg E, Plummer LN (2000) Dating young groundwater with sulfur hexafluoride: natural and anthropogenic sources of sulfur hexafluoride. Water Resour Res 36(10):3011-3030. doi:10.1029/ 2000WR900151

Cook P, Solomon D, Plummer L, Busenberg E, Schiff S (1995) Chlorofluorocarbons as tracers of groundwater transport processes in a shallow, silty sand aquifer. Water Resour Res 31(3):425-434. doi:10.1029/94WR02528

Cook PG, Böhlke J-K (2000) Determining timescales for groundwater flow and solute transport. In: Environmental tracers in subsurface hydrology. Springer, pp 1-30. doi:10.1007/978-1-4615-4557-6 1

Darling W, Gooddy D (2007) Assessing the applicability of global CFC and SF6 input functions to groundwater dating in the UK. Sci Total Environ 387(1-3):353-362. doi:10.1016/j.scitotenv. 2007.06.015

Denovan BA, Strand SE (1992) Biological degradation of chlorofluorocarbons in anaerobic environments. Chemosphere 24(7):935-940. doi:10.1016/0045-6535(92)90012-G

DeWalle D, Edwards P, Swistock B, Aravena R, Drimmie R (1997) Seasonal isotope hydrology of three Appalachian forest catchments. Hydrol Process 11(15):1895-1906

Dunkle S, Plummer L, Busenberg E, Phillips P, Denver J, Hamilton P, Michel R, Coplen T (1993) Chlorofluorocarbons (CCl3F and $\mathrm{CCl} 2 \mathrm{~F} 2$ ) as dating tools and hydrologic tracers in shallow groundwater of the Delmarva Peninsula, Atlantic Coastal Plain, United States. Water Resour Res 29(12):3837-3860. doi:10. 1029/93WR02073

Gooddy DC, Darling WG, Abesser C, Lapworth DJ (2006) Using chlorofluorocarbons (CFCs) and sulphur hexafluoride (SF6) to characterise groundwater movement and residence time in a lowland Chalk catchment. J Hydrol 330(1-2):44-52. doi:10. 1016/j.jhydrol.2006.04.011

Han L, Hacker P, Gröning M (2007) Residence times and age distributions of spring waters at the Semmering catchment area, Eastern Austria, as inferred from tritium, CFCs and stable isotopes. Isot Environ Health Stud 43(1):31-50. doi:10.1080/10256010601154015

Han DM, Song XF, Currell MJ, Tsujimura M (2012) Using chlorofluorocarbons (CFCs) and tritium to improve conceptual model of groundwater flow in the South Coast Aquifers of Laizhou Bay, China. Hydrol Processes 26(23):3614-3629. doi:10.1002/hyp. 8450

Happell JD, Price RM, Top Z, Swart PK (2003) Evidence for the removal of CFC-11, CFC-12, and CFC-113 at the groundwatersurface water interface in the Everglades. J Hydrol 279(1-4): 94-105. doi:10.1016/S0022-1694(03)00169-0

Happell JD, Opsahl S, Top Z, Chanton JP (2006) Apparent CFC and $3 \mathrm{H} / 3 \mathrm{He}$ age differences in water from Floridan Aquifer springs. J Hydrol 319(1-4):410-426. doi:10.1016/j.jhydrol.2005.07.033

Herzberg O, Mazor E (1979) Hydrological applications of noble gases and temperature measurements in underground water systems: examples from Israel. J Hydrol 41(3):217-231. doi:10.1016/ 0022-1694(79)90063-5

Horneman A, Stute M, Schlosser P, Smethie W Jr, Santella N, Ho DT, Mailloux B, Gorman E, Zheng Y, van Geen A (2008) Degradation rates of CFC-11, CFC-12 and CFC-113 in anoxic shallow aquifers of Araihazar, Bangladesh. J Contam Hydrol 97(1-2):27-41. doi:10.1016/j.jconhyd.2007.12.001

International Atomic Energy Agency (IAEA) (2006) Use of chlorofluorocarbons in hydrology - a guidebook, STI/PUB/1238. http:// www-pub.iaea.org/MTCD/publications/PDF/Pub1238_web.pdf

Jurgens BC, Böhlke J, Eberts SM (2012) Tracer LPM (version 1): an excel workbook ${ }^{\circledR}$ for interpreting groundwater age distributions from environmental tracer data: U.S. Geological Survey Techniques and Methods Report 4-F3, p 60

Kadlec RH, Wallace S (2008) Treatment wetlands. 2nd edn. CRC Press, Baca Raton
Katz BG, Plummer LN, Busenberg E, Revesz KM, Jones BF, Lee TM (1995) Chemical evolution of groundwater near a sinkhole lake, northern Florida: 2. Chemical patterns, mass transfer modeling, and rates of mass transfer reactions. Water Resour Res 31(6):1565-1584. doi:10.1029/95WR00220

Khalil M, Rasmussen R (1989) The potential of soils as a sink of chlorofluorocarbons and other man-made chlorocarbons. Geophys Res Lett 16(7):679-682. doi:10.1029/GL016i007p00679

Kirchner JW, Feng X, Neal C (2001) Catchment-scale advection and dispersion as a mechanism for fractal scaling in stream tracer concentrations. J Hydrol 254(1):82-101. doi:10.1016/S00221694(01)00487-5

Liu J, Chen Z, Wei W, Zhang Y, Li Z, Liu F, Guo H (2012) Using chlorofluorocarbons (CFCs) and tritium $(3 \mathrm{H})$ to estimate groundwater age and flow velocity in Hohhot Basin, China. Hydrol Processes. doi:10.1002/hyp.9659

Lovley DR, Woodward JC (1992) Consumption of freons CFC-11 and CFC-12 by anaerobic sediments and soils. Environ Sci Technol 26(5):925-929

Małoszewski P, Zuber A (1982) Determining the turnover time of groundwater systems with the aid of environmental tracers: 1 . Models and their applicability. J Hydrol 57(3):207-231. doi:10. 1016/0022-1694(82)90147-0

Małoszewski P, Rauert W, Stichler W, Herrmann A (1983) Application of flow models in an alpine catchment area using tritium and deuterium data. J Hydrol 66(1):319-330. doi:10.1016/00221694(83)90193-2

Mazor E (1972) Paleotemperatures and other hydrological parameters deduced from noble gases dissolved in groundwaters; Jordan Rift Valley, Israel. Geochim Cosmochim Acta 36(12):1321-1336. doi:10.1016/0016-7037(72)90065-8

Nguyen LM (2000) Organic matter composition, microbial biomass and microbial activity in gravel-bed constructed wetlands treating farm dairy wastewaters. Ecol Eng 16(2):199-221. doi:10.1016/S0925-8574(00)00044-6

Oster H, Sonntag C, Münnich K (1996) Groundwater age dating with chlorofluorocarbons. Water Resour Res 32(10):2989-3001. doi:10.1029/96WR01775

Owens I (1991) Effect of catchment-scale subsurface mixing on stream isotopic response. Water Resour Res 27(I2):3065-3073. doi:10.1029/91WR02025

Pearce A, Stewart M, Sklash M (1986) Storm runoff generation in humid headwater catchments: 1 . Where does the water come from? Water Resour Res 22(8):1263-1272. doi:10.1029/ WR022i008p01263

Plummer LN, Busenberg E (2000) Chlorofluorocarbons. In: Environmental tracers in subsurface hydrology. Kluwer, Boston, pp 441-478

Plummer LN, Busenberg E, Drenkard S, Schlosser P, Ekwurzel B, Weppernig R, McConnell J, Michel R (1998) Flow of river water into a karstic limestone aquifer-2. Dating the young fraction in groundwater mixtures in the upper Floridan Aquifer near Valdosta, Georgia. Appl Geochem 13(8):1017-1043. doi:10. 1016/S0883-2927(98)00032-8

Plummer LN, Busenberg E, Böhlke J, Nelms D, Michel R, Schlosser P (2001) Groundwater residence times in Shenandoah National Park, Blue Ridge Mountains, Virginia, USA: a multi-tracer approach. Chem Geol 179(1-4):93-111. doi:10.1016/S00092541(01)00317-5

Plummer LN, Ekwurzel B, Cook PG (2006) Principles of chlorofluorocarbon dating. In: Use of chlorofluorocarbons in hydrology-a guidebook. International atomic energy agency, Vienna, pp 17-29 (Chapter 13)

Rowland F, Molina MJ (1975) Chlorofluoromethanes in the environment. Rev Geophys 13(1):1-35. doi:10.1029/RG013i 001p00001

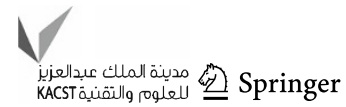


Seitzinger SP (1994) Linkages between organic matter mineralization and denitrification in eight riparian wetlands. Biogeochemistry 25(1):19-39. doi:10.1007/BF00000510

Selaolo ET (1998) Tracer studies and groundwater recharge assessment in the eastern fringe of the Botswana Kalahari: the Letlhakeng-Botlhapatlou area. ET Selaolo. doi:10.1029/ 96WR00068

Semprini AE, Levi-Setti P, Bozzo M, Ravizza M, Taglioretti A, Sulpizio P, Albani E, Oneta M, Pardi G (1992) Insemination of HIV-negative women with processed semen of HIV-positive partners. Lancet 340(8831):1317-1319. doi:10.1016/01406736(92)92495-2

Szabo Z, Rice D, Plummer L, Busenberg E, Drenkard S, Schlosser P(1996) Age dating of shallow groundwater with chlorofluorocarbons, Tritium/Helium: 3, and flow path analysis, Southern New Jersey Coastal Plain. Water Resour Res 32(4):1023-1038. doi:10.1029/ 96WR00068

Thompson T, Butler J, Daube B, Dutton G, Elkins J, Hall B, Hurst D, King D, Kline E, Lafleur B (2004) Halocarbons and other atmospheric trace species. Summ Rep 27(2002-2003):115-135

Toy TJ, Munson BE (1978) The prediction of mean monthly soil temperature from mean monthly air temperature. Soil Sci 126(3):181-189
Uhlenbrook S (2002) Hydrograph separations in a mesoscale mountainous basin at event and seasonal timescales. Water Resour Res 38(6). doi:10.1029/2001wr000938

Visser A, Schaap JD, Broers HP, Bierkens MF (2009) Degassing of $3 \mathrm{H} / 3 \mathrm{He}, \mathrm{CFCs}$ and SF6 by denitrification: measurements and two-phase transport simulations. J Contam Hydrol 103(3-4):206-218. doi:10.1016/j.jconhyd.2008.10.013

Vogel J, Talma A (1981) Gaseous nitrogen as evidence for denitrification in groundwater. J Hydrol 50:191-200

Walker SJ, Weiss RF, Salameh PK (2000) Reconstructed histories of the annual mean atmospheric mole fractions for the halocarbons CFC-11 CFC-12, CFC-113, and carbon tetrachloride. J Geophys Res: Oceans (1978-2012) 105(C6):14285-14296. doi:10.1029/ 1999JC900273

Warner M, Weiss R (1985) Solubilities of chlorofluorocarbons 11 and 12 in water and seawater. Deep Sea Res Part A Oceanogr Res Papers 32(12):1485-1497. doi:10.1016/0198-0149(85)90099-8

Wisegarver DP, Gammon RH (1988) A new transient tracer: measured vertical distribution of $\mathrm{CCl} 2 \mathrm{FCClF} 2(\mathrm{~F}-113)$ in the North Pacific Subarctic Gyre. Geophys Res Lett 15(2):188-191. doi:10.1029/GL015i002p00188 